\title{
Influence of milk production systems and practices on somatic cell count and total bacterial count in western Paraná
}

\section{Rodrigo Cesar dos Reis Tinini ${ }^{1 *}$ (iD), Maximiliane Alavarse Zambom ${ }^{2}$ iD, Marcel Moreira de Brito $^{3}$ (iD, Daniele Cristina da Silva Kazama ${ }^{4}$ iD, Cibele Regina Schneider ${ }^{3}$ (iD, Josias Luis Fornari $^{1}$ (iD), Maichel Jhonattas Lange ${ }^{1}$ (iD), Jéssica Gabi Dessbesell ${ }^{1}$ iD}

\footnotetext{
${ }^{1}$ Universidade Estadual do Oeste do Paraná, Programa de Pós-graduação em Zootecnia, Marechal Cândido Rondon, PR, Brasil.

2 Universidade Estadual do Oeste do Paraná, Departamento de Zootecnia, Marechal Cândido Rondon, PR, Brasil.

${ }^{3}$ Universidade Estadual de Maringá, Programa de Pós-graduação em Zootecnia, Maringá, PR, Brasil.

${ }^{4}$ Universidade Federal de Santa Catarina, Departamento de Zootecnia, Florianópolis, SC, Brasil.
}

\begin{abstract}
The objective of this study was to evaluate milk quality for somatic cell count (SCC) analysis and total bacterial count (TBC) in agroecological production systems and conventional systems, relating them to the frequency of milking practices and types of facilities. The study was conducted in 2013 and 2014, in the western region of Paraná State, Brazil. We used a semi-structured questionnaire to identify management practices of producers in the 17 dairy systems (DS) in the city of Diamante d'Oeste and the 27 DS in Toledo. Milk sampling was performed monthly. Data were analyzed using two statistical methods. These were then used to create cross tabulation of groups with production systems and practices that can influence product quality. Cluster classification analysis allowed grouping of the initial 44 production systems into three homogeneous groups: Group 1, with better quality regarding the normative instruction 62 (NI62), with average values of SCC $407.37($ cells $\times 1000 / \mathrm{mL})$ and TBC $210.50(\mathrm{cfu} \times 1000 / \mathrm{mL})$; Group 2, with SCC $328.50($ cells $\times 1000 / \mathrm{mL})$ and TBC $699.75(\mathrm{cfu} \times 1000 / \mathrm{mL})$, both outside the NI62 parameters; and Group 3, with SCC 680.25 (cells $\times 1000 / \mathrm{mL})$, considered low- and high-value TBC $1775.25(\mathrm{cfu} \times 1000 / \mathrm{mL})$, out of NI62. The results indicate that management practices and some other preventions adopted during milking are the determining factors of milk quality. Therefore, SCC and TBC levels are not determined by agroecological or conventional production systems, but rather, these levels are determined by the practices differentially adopted by the production systems.
\end{abstract}

Key Words: agroecology, cluster, dairy product, milk

\section{Introduction}

The milk production chain takes a prominent place in the actions of the Ministry of Agrarian Development (MDA) in Brazil. The importance is due to the fact that milk provides regular income to family farming, which highlights the necessity to permanently stimulate improvement of producers and qualified technical support to obtain a high-quality and sustainable product (Campos et al., 2012). Agroecology plays an important role in the construction of sustainable development in dairy cattle, in which there is socially fair and economically viable

Received: December 19, 2017

Accepted: July 31, 2018

*Corresponding author: rodrigotinini@gmail.com

Copyright (c) 2018 Sociedade Brasileira de Zootecnia. This is an Open Access article distributed under the terms of the Creative Commons Attribution License (http://creativecommons.org/licenses/by/4.0/), which permits unrestricted use, distribution, and reproduction in any medium, provided the original work is properly cited. production performed in an environmentally correct way (Balem and Silveira, 2002).

The few studies linking the management practices used in production systems with milk quality mainly focus on chemical compounds that are beneficial to human health. Agroecological milk production is expected to have a different chemical composition than milk produced by the conventional production system. It is expected to be different mainly in relation to contaminants and also in composition parameters (Bento et al., 2013).

Milk quality assessment must include chemical composition (total solids, fat, protein, lactose, and minerals), microbiological factors (total bacterial count), organoleptic factors (taste, odor, and appearance), and somatic cell count to fulfill internationally required parameters (Ribeiro et al., 2000). Milk must also be free from contaminants such as antibiotics, mycotoxins, and pesticide residues. Junior et al. (2012) pointed out that milk quality reflects practices involved in the production process, which are not equal in all production units. 
Western Paraná has the second largest dairy production in the state and is the region where agroecology is more present on family farms and in rural settlements. It is expected that the guidelines of agroecological production will be increasingly adopted in milk production. Thus, the objective of this study was to evaluate milk quality, via SCC and $\mathrm{TBC}$, and the milking practices and equipment which can interfere with product quality, in both agroecological and conventional production systems.

\section{Material and Methods}

The study was carried out from October 2013 to September 2014 in the western region of Paraná, Brazil, in the cities of Diamante d'Oeste $\left(24^{\circ} 56^{\prime} 34^{\prime \prime} \mathrm{S}\right.$ and $\left.54^{\circ} 6^{\prime} 10^{\prime \prime} \mathrm{W}\right)$

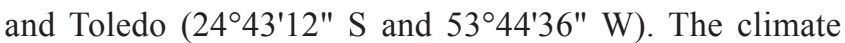
is classified as predominantly humid temperate, according to Köppen and Geiger (1928), and soil is predominantly Latosol and Nitosol.

The first study group was Ander Rodolfo Henrique settlement, old Comil farm, which has an area of 3,097.69 ha and is partly in Diamante d'Oeste city and partly in the western Vera Cruz city (Refati et al., 2017). Ander Rodolfo Henrique settlement adopted agroecology as a political decision to break the conventional model of agricultural production. The settlement coordination defined the agroecological matrix and standards such as non-use of hybrid seed, non-eucalyptus plantation, a ban on burning, and non-use of anthelmintics, acaricide, and botfly insecticide in animals (Coutinho et al., 2009). The settlement has 102 families, of which only 32 have a potential for agroecological production according to the Centro de Apoio ao Pequeno Agricultor (CAPA), a non-governmental organization that provides technical assistance to the rural settlement. In partnership with CAPA, a meeting was held with these 32 producers, and 17 producers that showed interest in participating in the study were selected.

The second study group was comprised of properties that provide milk for LactoBom industry, which processes and distributes pasteurized milk and milk products in Paraná. The industry has a total of 103 producers and suppliers, and this dairy preaches that was imposed at the beginning of the 1990's and requires excellence in milk quality. To this end, the dairy aids with production on the property, transportation, manufacturing, and distribution, thus ensuring a standard of quality in all sectors. In partnership with the dairy, 32 systems were selected for potential inclusion in the study, and of those, 27 systems showed interest in participating.
Forty-four milk producers were interviewed in loco with the support of a semi-structured questionnaire to identify management strategies adopted by producers. The script included questions about registration data, characterization of the owner and the farm, milk production and herd, feed, milking, reproductive management, sanitary control, and milk marketing.

Monthly milk samples were collected from 44 properties between October 2013 and September 2014, totaling 12 collections and covering all seasons. Samples were collected directly from the milk storage tank, with a sanitized stainlesssteel shell, in which the milk was homogenized, collected, and then packed in two standardized vials of $70 \mathrm{~mL}$ and kept below $5{ }^{\circ} \mathrm{C}$ until analysis. One sample was preserved by Bronopol ${ }^{\circledR}$ (2-bromo-2-nitropropane-1,3-diol) for somatic cell count (SCC) analysis, and the preservative azidiol was added to the other vial for analysis of total bacterial count (TBC). To perform the analysis, milk samples were shipped to the laboratory. Total somatic cell count was determined with Somacount $500^{\circledR}$ (Bentley Instruments Incorporated, Chaska, MN, USA) by flow cytometry, and TBC was determined by an electronic counter Bactocount IBC ${ }^{\circledR}$ (Bentley Instruments Incorporated, Chaska, MN, USA).

The creation of these variables followed the concept of the creation of "constructs", that is, an effort to give a statistical meaning to a concept to be evaluated (Barroso and Artes, 2003).

When necessary, the categories referring to each variable, so that the multiple correspondence analysis could be performed, were transformed and codified (Crivisqui, 1995; Pereira, 1999; Mingoti, 2005).

To analyze the qualitative data, we used Multiple Correspondence Analysis (MCA) (Lebart et al., 2000; Smith et al., 2002; Barroso and Artes, 2003), using SPSS 18.0 software, according to the statistical model:

$$
\begin{gathered}
X i j=Z i j \\
V_{\text {ri. }} \text { cj }
\end{gathered}
$$

The weights take into account the variable $\mathrm{Xij}$, being: $\mathrm{X}$ in its $i$-th observation for the $j$-th category (or level). The categories are exclusive, each case can only take one category per variable. To the MCA, the indicator matrix $\mathrm{Z}$ is applied with the $\mathrm{n}$ lines (dairy production systems or properties) and $p$ columns for nominal categories of the study variables. The matrix $\mathrm{Z}$ is standardized in each element for $\mathrm{X}$ by their respective profiles of line (ri) and column (cj).

All the mathematical and statistical procedures adopted to carry out this structuring and analysis followed the procedures described by De Leeuw (1984), Costa et al. (2008), and Lebart et al. (2000). 
Subsequently, the method of selection of the variables was performed by means of MCA, a methodology used for the exploration of categorical data, analogous to Factor Analysis, mainly used to graphically verify relations between categories of variables. The variables that obtained the highest contribution scores described in terms of explained variance (Kubrusly, 2001) and true adjustment to the original data (Crombach's $\alpha>0.75$ ) were maintained, and the variables were constructed, each one containing the levels of occurrence.

The creation of these variables followed the concept of the creation of "constructs", that is, an effort to give a statistical meaning to a concept to be evaluated (Barroso and Artes, 2003).

Data were processed and statistically analyzed using IBM SPSS Statistics ${ }^{\circledR}$ (version 18.0). Hierarchical cluster analysis was used to define similar producers grouped by milk quality, and cross-tabulation was then used to identify relationships between these groups and types of production systems adopted, practical milking, and equipment used in the milk production.

\section{Results}

The properties were studied in their homogeneity and characterized in relation to some managements. However, the formation of three groups (G1, G2, and G3) among the evaluated milk production systems can be observed (Figure 1).

Among the 19 variables studied and applied in the questionnaire, only 12 assumed higher values and had greater contribution to the accumulated variance and to compose the principal components 1 and 2, obtained using

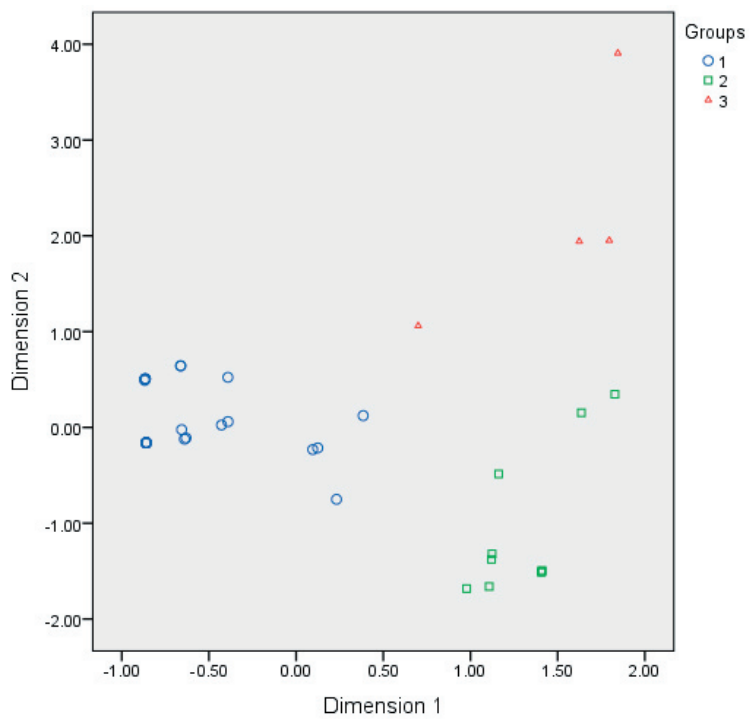

Figure 1 - Factorial representation of Multiple Correspondence Analysis and system clusters.
MCA. The most important variables within PC 1 (Principal Component 1) were: cooler type, milking system cleaning, milking room material, pre-dipping practice, total bacterial count, and black background mug test. The main variable that make up the PC 2 (Principal Component 2) were the management practices of teats drying, such as the material used for drying and cleaning the milking system (Table 1).

The cluster classification analysis (Table 2) categorized the initial 42 production systems into three groups (Group 1, Group 2, and Group 3). Group 1 was the largest group, with $30 \mathrm{DS}$, and was characterized by the best indices of SCC and TBC. This group was not compliant with the quality requirements of NI 62 , as the average values found were $210.50(\mathrm{cfu} \times 1000 / \mathrm{mL})$ for TBC and 403.372 (cells $\times$ $1000 / \mathrm{mL}$ ) for SCC. Those values are not considered good, given the reference at maximum $100(\mathrm{cfu} \times 1000 / \mathrm{mL})$ for TBC and 400 (cells $\times 1000 / \mathrm{mL}$ ) for SCC, in accordance with the provisions and updated in normative 62 of the Ministry of Agriculture. Group 1 does not currently follow updated NI 62 requirements, which stipulate maximum values of TBC as $100(\mathrm{cfu} \times 1000 / \mathrm{mL})$ and $\mathrm{SCC}$ as 400 (cells $\times 1000 / \mathrm{mL}$ ), starting from July 2016 in the Midwest, Southeast, and South, and from June 2017 in the North and Northeast. However, on May 3, 2016, the Ministry of Agriculture, Livestock and Supply published a new IN, number 7, which changes IN n. 62/2011, extending the stipulated deadlines for another two years from 2016, that is, TBC $300(\mathrm{cfu} \times 1000 / \mathrm{mL})$ and SCC $500($ cells $\times 1000 / \mathrm{mL})$ as of 7/1/2018. With this, the South, Southeast, and Midwest regions will have to conform to the norms until 2018, and the North and Northeast regions until 2019.

Group 2 consisted of ten farms that had quality parameters outside for TBC established by NI 62, with an average value of SCC within the NI 62 parameter -400 (cells $\times 1000 / \mathrm{mL}$ ). The average value of SCC for this group was 328.50 (cells $\times$ $1000 / \mathrm{mL})$ and $699.75(\mathrm{cfu} \times 1000 / \mathrm{mL})$ for TBC.

Table 1 - Contributions of the components of the factorial analysis to the eigenvalues and percentage of variance explained

\begin{tabular}{lccc}
\hline Component & Eigenvalue & \% of variance & $\begin{array}{c}\text { Cumulative } \\
\text { variance }\end{array}$ \\
\hline 1 & -6.63 & 49.4 & 49.4 \\
2 & -1.92 & 22.5 & 71.9 \\
\hline
\end{tabular}

Table 2 - Groupings of dairy systems (DS) on the sanitary quality

\begin{tabular}{lccc}
\hline Group & Group 1 & Group 2 & Group 3 \\
\hline DS per group & 30 & 10 & 4 \\
SCC $($ cells $\times 1000 / \mathrm{mL})$ & 407.37 & 328.50 & 680.25 \\
TBC $(\mathrm{cfu} \times 1000 / \mathrm{mL})$ & 210.50 & 699.75 & 1775.25 \\
\hline
\end{tabular}

SCC - somatic cell count; TBC - total bacterial count. 
Group 3 consisted of four DS that had quality parameters outside for those established by NI 62 - but with extremely high values exceeding the quality parameters set by law for TBC, i.e., an average value of 1775.25 $(\mathrm{cfu} \times 1000 / \mathrm{mL})$.

Table 3 shows the frequencies of agroecological and conventional production systems for each group. Note that Group 1, which had the best milk quality, consists of more conventional DS with $90 \%$ conventional and $10 \%$ agroecological producers. This proportion tends to reverse in the groups with lower milk quality, where agroecological producers represent $100 \%$ in Group 2 and $100 \%$ in Group 3.

Considering the importance of the practices adopted, in product quality information, it is possible to identify the characteristics of each group, which may help explain the differences in milk quality.

The structures and equipment used (Table 4) can directly influence milk quality. Group 1 primarily used channeled mechanics $(80 \%)$. In group $2,62.50 \%$ of the farms used the milking mechanical bucket and nobody used mechanical channels. Group 3 was divided into $75 \%$ manual milking and $25 \%$ milking mechanical bucket.

Regarding the type of cooler, $96.67 \%$ of Group 1 producers had a bulk tank, followed by $3.33 \%$ with a dip tank, and $0.00 \%$ cooled the milk in a freezer. In Group 2, dip tank was most common $(90.00 \%)$ and $10.00 \%$ used a bulk tank. In Group 3, 75.00\% producers used the dip tank

Table 3 - Frequency of agroecological and conventional base systems in groups formed

\begin{tabular}{lcccccc}
\hline System & $\mathrm{N}$ & $\begin{array}{c}\text { Group 1 } \\
(\%)\end{array}$ & $\mathrm{N}$ & $\begin{array}{c}\text { Group 2 } \\
(\%)\end{array}$ & $\mathrm{N}$ & $\begin{array}{c}\text { Group 3 } \\
(\%)\end{array}$ \\
\hline Agroecological & 3 & 10.00 & 10 & 100.00 & 5 & 100.00 \\
Conventional & 27 & 90.00 & 0 & 0.00 & 0 & 0.00 \\
\hline
\end{tabular}

Table 4 - Structure for carrying out the milking and milk storage in groups formed

\begin{tabular}{lcccc}
\hline \multirow{2}{*}{ Variable } & & \multicolumn{3}{c}{ Group } \\
\cline { 3 - 5 } & & 1 & 2 & 3 \\
\hline Type of milking (\%) & Manual & 0.00 & 37.50 & 75.00 \\
& Mechanical bucket & 20.00 & 62.50 & 25.00 \\
& Channeled & 80.00 & 0.00 & 0.00 \\
& Total & 100.00 & 100.00 & 100.00 \\
Type of cooler (\%) & Freezer & 0.00 & 0.00 & 0.00 \\
& Dip tank & 3.33 & 90.00 & 75.00 \\
& Bulk tank & 96.67 & 10.00 & 25.00 \\
Milking parlor material (\%) & Total & 100.00 & 100.00 & 100.00 \\
& TF + GF & 0.00 & 10.00 & 10.00 \\
& TF + CF & 0.00 & 80.00 & 80.00 \\
& Masonry & 100.00 & 10.00 & 10.00 \\
& Total & 100.00 & 100.00 & 100.00 \\
\hline
\end{tabular}

$\mathrm{TF}+\mathrm{GF}$ - timber frame and ground floor; $\mathrm{TF}+\mathrm{CF}$ - timber frame and concrete floor. for cooling milk. A characteristic of Group 1 was to adopt more technology to cool milk than Groups 2 and 3.

Regarding the type of milking parlor material, the predominant room type for all groups was with masonry walls and concrete floor. This room type was present in $100.00 \%$ DS in Group 1, 10.00\% in Group 2, and 100.00\% in Group 3. Group 2 had more producers with a timberframe milking parlor and concrete floor, representing $80.00 \%$, respectively.

The correct use and hygiene of technologies is more important than simply owning the technologies. All Group 1 producers $(100.00 \%)$ cleaned coolers with every milk collection (Table 5). In Group 2, this practice was also reported in $20.00 \%$ of cases, while $40.00 \%$ cleaned every 15 days, and $40.00 \%$ cleaned at intervals greater than 15 days. In Group 3, cooler cleaning occurred in $25.00 \%$ of cases every 15 days and $25.00 \%$ over 15 days, which may explain why TBC levels were so high in this group.

The majority of producers in groups 1 and 2 cleaned milking equipment after each milking, that is, 100.00 and $80.00 \%$, respectively. This practice vary greatly between the groups and, in this case, has a significant impact on milk quality of the studied producers, given the fact that in Group 3, for example, $25 \%$ of the producers follow this practice once a week, and $75.00 \%$ never cleaned; and this that had the worst average TBC.

Milking practices involving cleaning and disinfection of cow teats can directly influence milk quality. The DS in Group 1 had the highest frequency of pre-dipping application $(80.00 \%)$, followed by Group 2 with only $20.00 \%$, and no farms in Group 3 (Table 6). Similar data were observed for post-dipping: $90.00 \%$ of DS for Group $1,25.00 \%$ for Group 3, and Group 2 had no producer performing that practice.

With respect to how teats are dried after pre-dipping, Groups 1 and 2 most commonly used cotton cloths, in 66.70 and $90.00 \%$ of cases, respectively. According to NI 62, the most suitable method is to use disposable paper because it

Table 5 - Framework for completion of milking and milk storage in groups formed

\begin{tabular}{lcccc}
\hline \multirow{2}{*}{ Variable } & & \multicolumn{3}{c}{ Group } \\
\cline { 3 - 5 } & & 1 & 2 & 3 \\
\hline Cleaning frequency & $>15$ days & 0.00 & 40.00 & 25.00 \\
of milk cooler (\%) & 15 days & 0.00 & 40.00 & 25.00 \\
& Every collection & 100.00 & 20.00 & 50.00 \\
& Total & 100.00 & 100.00 & 100.00 \\
Cleaning frequency & Once a week & 0.00 & 0.00 & 25.00 \\
of milking system (\%) & Twice a week & 0.00 & 10.00 & 0.00 \\
& After every milking & 100.00 & 80.00 & 0.00 \\
& Never & 0.00 & 10.00 & 75.00 \\
& Total & 100.00 & 100.00 & 100.00 \\
\hline
\end{tabular}


is more hygienic, but only $33.30 \%$ in Group 1 adopted this practice, followed by $25.00 \%$ in Group 3, and no DS in Group 2 used this method.

The importance of pre- and post-dipping is demonstrated by the fact that the DS that included these management practices had a lower annual average of SCC and $\mathrm{TBC}$, as observed in Group 1. In systems in which less than $50 \%$ of DS carry out this practice, SCC and TBC values directly reflect this, and they are the groups with lower milk quality, as in Groups 2 and 3.

The mastitis detection and control methods considered were the black background mug, for detection of clinical cases, and the CMT (California mastitis test), for detection of subclinical cases (Table 7). Overall, the black background mug method was used infrequently: in Group 1, only $40.00 \%$ performed this practice; in Groups 2 and 3, respectively, 10.00 and $25.00 \%$. As for the CMT, $83.30 \%$ of producers in Group 1 used it, while only $20.00 \%$ of farms in Group 2 used it, and just 25\% producer in Group 3 conducted this test. These findings may explain the low use of the black background mug method by Group 1, because the CMT test detects inflammation before the most critical signs, so the daily test is not necessary. This is also one of the reasons that Group 1 had the lowest SCC average.

Table 6 - Performance of teat hygiene practices at milking in groups formed

\begin{tabular}{|c|c|c|c|c|}
\hline \multirow{2}{*}{ Variable } & & \multicolumn{3}{|c|}{ Group } \\
\hline & & 1 & 2 & 3 \\
\hline \multirow[t]{3}{*}{ Pre-dipping frequency $(\%)$} & Yes & 80.00 & 20.00 & 0.00 \\
\hline & No & 20.00 & 80.00 & 100.00 \\
\hline & Total & 100.00 & 100.00 & 100.00 \\
\hline \multirow[t]{3}{*}{ Post-dipping frequency $(\%)$} & Yes & 90.00 & 0.00 & 25.00 \\
\hline & No & 10.00 & 100.00 & 75.00 \\
\hline & Total & 100.00 & 100.00 & 100.00 \\
\hline \multirow[t]{4}{*}{ Teats drying (\%) } & No drying & 0.00 & 10.00 & 50.00 \\
\hline & Cloth & 66.70 & 90.00 & 25.00 \\
\hline & Paper & 33.30 & 0.00 & 25.00 \\
\hline & Total & 100.00 & 100.00 & 100.00 \\
\hline
\end{tabular}

Table 7 - Performance of preventive practices to mastitis in dairy animals in groups formed

\begin{tabular}{lcccc}
\hline \multirow{2}{*}{ Variable } & & \multicolumn{3}{c}{ Group } \\
\cline { 3 - 5 } & & 1 & 2 & 3 \\
\hline Black background mug (\%) & Yes & 40.00 & 10.00 & 25.00 \\
& No & 60.00 & 90.00 & 75.00 \\
& Total & 100.00 & 100.00 & 100.00 \\
CMT (\%) & Yes & 83.30 & 20.00 & 25.00 \\
& No & 16.70 & 80.00 & 75.00 \\
Homeopathy (\%) & Total & 100.00 & 100.00 & 100.00 \\
& Yes & 46.70 & 50.00 & 75.00 \\
& No & 53.30 & 50.00 & 25.00 \\
& Total & 100.00 & 100.00 & 100.00 \\
\hline
\end{tabular}

CMT - California mastitis test.
The use of homeopathy in a preventive manner was performed by $46.70 \%$ of Group 1 . Group 2, which is the group that had the highest SCC average, was also the group with producers using homeopathy $(50.00 \%)$, which suggests an import role for this method in animal health and milk quality.

\section{Discussion}

The results of the present study are similar to those found by Carrillo et al. (2011), who obtained $71 \%$ of variance explained when studying dairy production systems in the metropolitan region of Maule, Chile. These values are very close to those observed by Betancourt et al. (2005), who studied milk production systems in the region of Nicaragua and observed about $45 \%$ of total variance. Tadielo et al. (2016) obtained values of $55 \%$ of accumulated variance in research conducted in dairy macroregions in the state of Rio Grande do Sul, Brazil. Bodenmüller Filho et al. (2010) achieved $56.51 \%$ of cumulative variance when studying, in the region of Londrina in Paraná state, Brazil, the diversity of milk production systems. Larger values were observed by Lange et al. (2017), who obtained 71.9\% in property analyses in the region of Marechal Candido Rondon, in Paraná, Brazil.

The main factor that interferes in the milk quality is the $\mathrm{TBC}$, which was the main responsible for the formations of the cluster and determines a fundamental role in milk hygiene.

According to Figueiredo et al. (2012), TBC is directly related to the hygiene of utensils used during milking, as well as to proper storage of the milk after its collection. It is a factor that can be modified quickly and easily due to its link to failures in correct cleaning and disinfection. High average TBC in Groups 2 and 3, therefore, indicates a failure in this regard.

Kuhnen et al. (2015) studied the characteristics and milk quality of production units in organic systems in Santa Catarina State, Brazil, and assessed milk-producing units in relation to SCC and TBC. The authors identified three groups, classified according to SCC 284.76 (cells $\times$ $1000 / \mathrm{mL}-\mathrm{G} 1), 416.79($ cells $\times 1000 / \mathrm{mL}-\mathrm{G} 2)$, and 627.75 (cells $\times 1000 / \mathrm{mL}-\mathrm{G} 3$ ). The values obtained for TBC were $1242.08(\mathrm{cfu} \times 1000 / \mathrm{mL}-\mathrm{G} 1), 2771.36(\mathrm{cfu} \times 1000 / \mathrm{mL}-\mathrm{G} 2)$, and $173.25(\mathrm{cfu} \times 1000 / \mathrm{mL}-\mathrm{G} 3)$. The main problem may be TBC, with two groups extremely outside the quality standards. Therefore, it is worrying that two of the three groups in the present study were outside institutional quality standards. However, Group 1, the largest group, contained the best milk quality and was fully within the requirements, meaning that most of the producers considered in this study can be considered to produce quality product. 
There was a tendency towards lower-quality product in groups that included a majority of agroecological production systems. However, the data also indicate that there can be a high quality standard in this production system, as demonstrated by Group 1, despite the limitations and difficulties created by restrictions on the use of chemicals. For example, according to NI 46, food from activities involving transgenics or pesticide handling to manufacturing is not allowed (Brasil 2011). However, for Fernandez et al. (2009), SCC control in small Brazilian ecological farms (agroecological, organic, and biodynamic) will prove ineffective as long as factors such as food handling, nutrition, milking, and general and mammary gland health do not occur satisfactorily. In addition, we observed that SCC and TBC did not differ by type of systems but, rather, by the management practices adopted.

Milking system type mainly affects TBC values. Taffarel et al. (2013) evaluated the TBC of 1,232 milk producers in western Paraná, Brazil, in 2006, and observed that the DS using manual milking systems and a milking mechanical bucket also had higher TBC values.

Taffarel et al. (2013), Cordioli and Oldra (2009), and Rosa et al. (2013) evaluated several DS and concluded that the bulk tank cooler type is more efficient. According to Fonseca and Santos (2000), milk must be refrigerated at $4{ }^{\circ} \mathrm{C}$ within $2 \mathrm{~h}$ after milking. If this does not happen, there is a proliferation of unwanted microorganisms and increased TBC values. This fact may also explain the quality difference we observed between producer groups.

The type of material used in milking parlor, such as timber frame, can negatively impact environmental hygiene. Picoli et al. (2014) evaluated milking management as a risk factor for the occurrence of microorganisms in raw milk. They studied timber frame and masonry milking parlors in 274 DS in six cities in southern Rio Grande do Sul State, Brazil. The authors found a higher presence of microorganisms in timber frame milking parlors with ground floors and concluded that milking parlor facilities have the greatest influence on the occurrence of infectious agents in milk.

Rangel et al. (2014) evaluated the relationship of cooling tank cleaning practices and milking equipment to milk TBC values for farms in Rio Grande do Norte State, Brazil, and found that TBC values are directly linked with cleaning equipment and the storage tank. Similarly, we observed that Group 1, which had better product quality, also had a higher frequency of cleaning, i.e., after every milk collection.

According to Fagundes et al. (2006), the goal of cooling the milk immediately after milking is to reduce the microbial growth; however, its effectiveness is maximized in conjunction with other factors, especially of hygienic order. The frequency of cleaning the utensils used for milking and milk storage is essential to maintain milk hygiene after secretion from the mammary gland.

Fariña et al. (2008) evaluated 14 dairy farms in Cascavel and Guaraniaçu cities, PR, Brazil, and found that cleaning the bulk tanks is done after every withdrawal of milk by the dairy, i.e., every $48 \mathrm{~h}$, and dip tanks were cleaned on average every 15 days. They also found that all farms performed complete cleaning of the milking equipment after each milking, data similar to that observed in this study, in which only three systems did not perform a cleaning set after each milking.

According to Cordioli and Oldra (2009), systems that use pre-dipping and dry teats with a paper towel have a TBC rate below $750(\mathrm{cfu} \times 1000 / \mathrm{mL})$. In addition to premilking management, it is important to carry out teat cleaning procedures after milking. Müller et al. (2002) stated that combining this with post-dipping results in a reduction of up to $50 \%$ of mastitis infections. Silva and Nogueira (2010) also highlighted the importance of using paper disposable towels for drying teats, because mastitis is mainly transmitted by colonization of the skin of teats, and occurs during milking via the hands of the milker, a contaminated cloth, or sponge contaminated being used to dry the teats in other cows, the presence of residual milk in liners, or inadequate milking equipment.

Detection of mastitis is critical, and according to Langoni (2013), the attention of the milker is important for efficient diagnosis. The main signs of clinical cases are changes in milk characteristics, such as color, and the appearance of lumps, pus, and blood. In cases of subclinical mastitis, the symptoms are not apparent; therefore, routine and preventive practices are important. The same result was reported by Sousa et al. (2011), who evaluated 122 family farms in the northwestern and central regions of Rio de Janeiro State, Brazil, and observed that the black background mug test, despite being a simple form of diagnosis for mastitis, was not conducted in $83.3 \%$ of farms in the northwest region and in $58.9 \%$ in the central region. Additionally, CMT tests were performed in only $5.5 \%$ of cases.

According to Mangieri Junior et al. (2015), homeopathy is considered low cost, because it allows producers to avoid the milk disposal necessary when using antibiotics and makes subclinical mastitis treatment during lactation possible, which both improve cost-effectiveness.

Radis et al. (2013) conducted a study in DS in Teixeira Soares city, PR, Brazil, and verified the effectiveness of homeopathy through SCC and TBC analysis. The authors 
observed that bovine mastitis was reduced with four months of use. Homeopathic preventive treatments have been shown to be effective with continued use, but there is a need for additional information and scientific studies to correlate treatment with changes in milk quality.

Sato et al. (2005) evaluated the difference in milk quality between organic and conventional systems and found no difference in the SCC values. They concluded that SCC values depend on the quality of health management and milking rather than on the production system. Similarly, we found that TBC values, and milk quality, were defined by management strategies and not the DS.

\section{Conclusions}

Milking practices and management strategies determine if a dairy system has better milk quality as measured by somatic cell count and total bacterial count. We noted a tendency by agroecological producers to not adopt some practices, resulting in a negative impact on milk quality and even failing to meet quality standards required by NI 62 . However, it is also possible to produce quality milk in both systems, which emphasizes the importance of conducting technical assistance and rural extension for milk producers in western Paraná State, especially in the cities studied.

\section{Acknowledgments}

We thank the Coordenação de Aperfeiçoamento de Pessoal de Nível Superior (CAPES), for research support, and Secretaria da Ciência, Tecnologia e Ensino Superior (SETI - Paraná), for the financial support.

\section{References}

Balem, T. A. and Silveira, P. R. 2002. Agroecologia: além de uma ciência, um modo de vida e uma política pública. In: V Simpósio Latino-americano sobre Investigação e Extensão em Sistemas Agropecuários - IESA e V Encontro da Sociedade Brasileira de Sistemas de Produção - SBSP. Available at: <http://www.ufsm.br/ desenvolvimentorural/textos/01.pdf> . Accessed on: Dez. 13, 2017.

Barroso, L. P. and Artes, R. 2003. Análise multivariada. In: Anais do Simpósio de Estatística Aplicada à Experimentação Agronômica. Universidade Federal de Lavras, Departamento de Ciências Exatas, Lavras. 152p.

Bento, L. L.; Moacyr, J. R.; Navarro, B. B.; Maraschin, M.; Machado Filho, L. C. P. and Kuhnen, S. 2013. Effects of conventional versus agroecological management on carotenoids and vitamin a contents in milk produced in the Western of Santa Catarina: seasonal variation. Veterinária e Zootecnia 20:80-82.

Betancourt, K.; Ibrahim, M.; Villanueva, C. and Vargas, B. 2005. Caracterización del manejo productivo de sistemas lecheros en la cuenca del río Bulbul de Matiguás, Matagalpa, Nicaragua. Livestock Research for Rural Development 17(7):1-12.
Bodenmüller Filho, A.; Damasceno, J. C.; Previdelli, I. T. S.; Santana, R. G.; Ramos, C. E. C. O. and Santos, G. T. 2010. Typology of production systems based on the milk characteristics. Revista Brasileira de Zootecnia 39:1832-1839. https://doi.org/10.1590/ S1516-35982010000800028

Brasil. Ministério da Agricultura, Pecuária e Abastecimento. 2011. Instrução Normativa n. 62, de dezembro de 2011. Brasília, DF.

Campos, S. A. C.; Coelho, A. B. and Gomes A. P. 2012. Influência das condições ambientais e ação antrópica sobre a eficiência produtiva agropecuária em Minas Gerais. Revista de Economia e Sociologia Rural 50:563-576.

Carrillo L., B.; Moreira L., V. H. and González V., J. 2011. Caracterización y tipificación de sistemas productivos de leche en la zona centrosur de Chile: un análisis multivariable. IDESIA (Chile) 29:71-81.

Crivisqui, E. 1995. Présentation de l'analyse factorielle des correspondances simples et multiples: Programe de Recherche et D'Enseignement em Statistique Appliquée (PRESTA). Université Libre de Bruxelles, Belgique. 162p.

Cordioli, E. and Oldra, A. 2009. Sistemas de produção de leite e qualidade do produto final na agricultura familiar. Revista Brasileira de Agroecologia 4:4493-4496.

Coutinho, A. D. A. L. 2009. Assentamento Ander Rodolfo Henrique: A Ruptura política e a transição tecnológica para a agroecologia. Available at: <http://aba-agroecologia.org.br/revistas/index.php/ rbagroecologia/article/view/7836>. Accessed on: Dec. 13, 2017.

Costa, J. C. G. D.; Infantosi, A. F. C.; Almeida, R. M. V. R. and Ramiarina, R. 2008. Análise de correspondência múltipla na avaliação de deslocamento inter-municipal para parto. p.327-330. In: $21^{\circ}$ Congresso Brasileiro de Engenharia Biomédica. CEFETBA, Salvador.

De Leeuw, J. 1984. Canonical analysis of categorical data. DSWO Press, Leiden.

Fagundes, C. M.; Fischer, V.; Silva, W. P.; Carbonera, N. and Araújo, M. R. 2006. Presença de Pseudomonas spp em função de diferentes etapas da ordenha com distintos manejos higiênicos e no leite refrigerado. Ciência Rural 36:568-572. https://doi.org/10.1590/ S0103-84782006000200032

Fariña, L. O.; Falconi, F. A.; Bulhões, R.; Iark, A. K.; Tessaro, A. B.; Salvatti, F.; Tavares, J. A.; Corrêa, J. M.; Sosa, D. E. F.; Ferreira, R. and Torres, E. F. 2008. Avaliação das condições higiênicosanitárias em estabelecimentos da agricultura familiar envolvidos na pecuária leiteira dos municípios de Cascavel e Guaraniaçu/PR. Revista Conexão UEPG 4:84-87.

Fernandez, V. N. V.; Zanela, M. B.; Pinto, A. T. and Ribeiro, M. E. R. 2009. Qualidade do leite ecológico produzido em uma unidade de produção do Rio Grande do Sul. Acta Scientiae Veterinariae $37: 45-48$.

Figueiredo, A. P. G.; Pereira, M. M.; Cunha, A. F.; Alves, J. R. and Cerqueira, M. M. O. P. 2012. Qualidade do leite de propriedades da área de proteção ambiental da bacia do córrego da velha no município de Luz (MG). Ciência Equatorial 2:34-53.

Fonseca, L. F. L. and Santos, M. V. 2000. Qualidade do leite e controle de mastite. Lemos Editorial, São Paulo. p.39-141.

Junior, J. F. L.; Ramos, C. E. C. O.; Santos, G. T.; Grande, P. A.; Damasceno, J. C. and Massuda, E. M. 2012. Análise das práticas de produtores em sistemas de produção leiteiros e seus resultados na produção e qualidade do leite. Semina: Ciências Agrárias 33:1199-208.

Köppen, W. and Geiger, R. 1928. Klimate der Erde, wall map. Verlag Justus Perthes, Gotha.

Kubrusly, L. S. 2001. Um procedimento para calcular índices a partir de uma base de dados multivariados. Pesquisa Operacional 21:107-117.

Kuhnen, S.; Stibuski, R. B.; Honorato, L. A. and Machado Filho, L. C. P. 2015. Farm management in organic and conventional dairy 
production systems based on pasture in Southern Brazil and its consequences on production and milk quality. Animals 5:479-494.

Lange, M. J.; Zambom, M. A.; Pozza, M. S. S.; Simões, G. H.; Fernandes, T.; Tinini, R. C. R.; Fornari, J. L and Anschau, F. A. 2017. Tipologia de manejo de ordenha: análise de fatores de risco para a mastite subclínica. Pesquisa Veterinária Brasileira 37:12051212. https://doi.org/10.1590/S0100-736X2017001100004

Langoni, H. 2013. Qualidade do leite: utopia sem um programa sério de monitoramento da ocorrência de mastite bovina. Pesquisa Veterinária Brasileira 33:620-626. https://doi.org/10.1590/S0100736X2013000500012

Lebart, L. 2000. Contiguity analysis and classification. p.233-244. In: Data analysis. Gaul, W.; Opitz, O. and Schader, M., eds. Springer, Berlin.

Mangieri Junior, R.; Benites, N. R. and Melville, P. A. 2015. Avaliação de tratamento homeopático na mastite ovina subclínica. Veterinária e Zootecnia 22:455-464.

Mingoti, S. A. 2005. Análise de dados através de métodos de estatística multivariada: uma abordagem aplicada. UFMG, Belo Horizonte. 297 p.

Müller, E. E. 2002. Qualidade do leite, células somáticas e prevenção da mastite. Simpósio sobre Sustentabilidade da Pecuária Leiteira na Região Sul do Brasil. p.206-217. In: Anais do II Sul- Leite: Simpósio sobre Sustentabilidade da Pecuária Leiteira na Região Sul do Brasil, Toledo.

Pereira, J. C. R. 1999. Análise de dados qualitativos: estratégias metodológicas para as ciências da saúde, humanas e sociais. EDUSP, São Paulo. 157p.

Picoli, T.; Zani, J. L.; Bandeira, F. S.; Roll, V. F. B.; Ribeiro, M. E. R.; Vargas, G. D. A.; Hübner, S. O.; Lima, M.; Meireles, M. C. A. and Fischer, G. 2014. Manejo de ordenha como fator de risco na ocorrência de microorganismos em leite cru. Semina: Ciências Agrárias 35:2471-2480.

Ribeiro, M. E. R.; Stumpf Júnior, W.; Buss, H.; Alves, G. C.; Martins, P. R. and Conto, O. 2000. Qualidade de leite. p.175-195. In: Sistemas de pecuária de leite: uma visão na região de clima temperado. Bitencourt, D.; Pegoraro, L. M. C.; Gomes, J. F.; Vetromila, M. A. M.; Ribeiro, M. E. R. and Stumpf Júnior, W. Embrapa Clima Temperado, Pelotas.
Radis, A. C.; Teleginski, M.; Martins, J.; Souza, A. L. and Goetten, S. 2013. Experiência com utilização de homeopatia em assentamentos no município de Teixeira Soares - PR. Available at: $<$ http://abaagroecologia.org.br/revistas/index.php/cad/article/view/15162> Accessed on: Dez. 13, 2017.

Rangel, A. H. N.; Araújo, V. M. and Lima Júnior, D. M. 2014. Processo de higienização nos equipamentos de ordenha em propriedades leiteiras. Acta Veterinaria Brasilica 8:107-112. https://doi.org/ 10.21708/avb.2014.8.2.3421

Refati, D. C.; Fabrini, J. E. and Marschner, W. R. 2017. O trabalho das mulheres nos assentamentos Antonio Companheiro Tavares em São Miguel do Iguaçu e Ander Rodolfo Henrique em Diamante do Oeste - Paraná. Revista Nera 20(35):83-107.

Rosa, G. S.; Rosvadoski, C. S. R.; Oliveira, Z. C.; Mouro, G. F.; Diniz, E. R. and Silva, V. R. G. 2013. Boas práticas de ordenha utilizadas por bovinocultores de leite em Ivaiporã-PR. Cadernos de Agroecologia 8(2):1-5.

Santos, M. and Fonseca, L. 2000. Qualidade do leite e controle de mastite. São Paulo, Lemos. 175p.

Sato, K.; Bartlett, P. C.; Erskine, R. J. and Kaneene, J. B. 2005. A comparison of production and management between Wisconsin organic and conventional dairy herds. Livestock Production Science 93:105-115.

Silva, M. V. M. and Nogueira J. L. 2010. Mastite: controle e profilaxia no rebanho bovino. Revista Científica Eletrônica de Medicina Veterinária 8(15):1-13.

Smith R., R.; Moreira L., V. and Latrille L., L. 2002. Caracterización de sistemas productivos lecheros en la $\mathrm{X}$ región de Chile mediante análisis multivariable. Agricultura Técnica 62:375-395.

Sousa, M. R. P.; Ristow, A. M.; Nogueira, E. B.; Torres Filho R. A. and Cortez, M. A. S. 2011. Caracterização de pequenas unidades produtoras de leite na região Centro e Noroeste do estado do Rio de Janeiro. Revista Brasileira de Ciência Veterinária 18:79-84.

Tadielo, L. E.; Bremm, T.; Alvarez, C.; Kessler, E.; Altermann, O. D. C. and Castagnara, D. D. 2016. Diagnóstico dos sistemas de produção das macrorregiões noroeste, centro ocidental e sudoeste Rio-Grandense. Anais do Salão Internacional de Ensino, Pesquisa e Extensão 8(2).

Taffarel, L. E.; Costa, P. B.; Oliveira, N. T. E.; Braga, G. C. and Zonin, W. J. 2013. Contagem bacteriana total do leite em diferentes sistemas de ordenha e de resfriamento. Arquivos do Instituto Biológico 80:7-11. https://doi.org/10.1590/S1808-16572013000100002 